УДК 338.64

\title{
СТРАТЕГІЧНІ ВЕКТОРИ ЕКОЛОГО-ЕКОНОМІЧНОГО РОЗВИТКУ НАЦІОНАЛЬНИХ ЕКОНОМІК
}

\section{STRATEGIC VECTORS OF ECOLOGICAL AND ECONOMIC DEVELOPMENT OF NATIONAL ECONOMIES}

\author{
Стройко Тетяна Володимирівна \\ доктор економічних наук, профресор, \\ Миколаївський національний університет імені В.О. Сухомлинського \\ ORCID: https://orcid.org/0000-0002-0044-4651 \\ Дохнянська Вікторія Вікторівна \\ студентка, \\ Миколаївський національний університет імені В.О. Сухомлинського \\ ORCID: https://orcid.org/0000-0001-5995-8852 \\ Stroiko Tetiana, Dokhnianska Victoria \\ Mykolayiv National University named after V.O. Sukhomlynsky
}

\begin{abstract}
У статті досліджено підходи до оцінювання стратегічних орієнтирів рівня еколого-економічного розвитку країн світу та обґрунтування запровадження індексу інклюзивного розвитку як принципу аналізу економічної, екологічної та соціальної структури світової економіки. Досліджено поняття інклюзивного зростання. Проаналізовано основні показники та методику фрормування індексу інклюзивного розвитку (IDI). Проаналізовано еколого-економічний стан топ 10 країн світу та України за індексом інклюзивного розвитку (IDI). Відповідно до індексу IDI Україну віднесено до країн, що розвиваються. Визначено, що серед них Україна має один із найнижчих рівнів доходів (49 з 79). Причиною даної ситуації можна назвати нерівномірний розподіл багатства щодо всього населення країни: високий рівень «тіньової» економіки; корупційні надприбутки; а також необхідно відмітити, більша частина доходів трудових мігрантів теж знаходяться в тіні; недостовірною статистикою щодо рівня доходів громадян тощо. Усе це приводить до все більшого розриву між багатими та бідними, скорочуючи середній клас. Україна на основі досвіду розвинених країн може провести заходи, ресрорми тощо спрямовані на економічний розвиток, покращення соціального та екологічного стану, знизити навантаження на менш захищений шар громадян країни на різних рівнях (оподаткування, дотації, вільне отримання освітніх послуг, медичної допомоги тощо). Можна стверджувати, що економічний, соціальний, екологічний розвиток України в порівнянні з розвиненими країнами характеризується нерівномірністю. А отже, створює необхідність у нових підходах, концепціях, моделях для зменшення диспропорційності України. Відмічено, що низький показник інклюзивного розвитку України свідчить про наявність інфраструктурних проблем, недоліків в диверсисрікації економіки, загроз для інвестиційного клімату та екологічні проблеми (радіаційне забруднення, стан атмосферного повітря, стан водних ресурсів, деградація ґрунтів, відходи, втрата біорізноманіття тощо). 3 цієї позиції концепція інклюзивного розвитку може забезпечити реалізацію принципів стабільного та збалансованого економічного, соціального та екологічного розвитку. Для України прийняття до уваги досвід розвинених країн, розробка та реалізація інклюзивно-орієнтованих програм дасть змогу стабілізувати соціально-економічну ситуацію в країні, а також зменшити нерівномірність у різних сфрерах суспільного життя, фрормуючи таку відкриту політику та економіку, яка передбачала б залучення всіх верств населення до участі в розподілі ресурсів і вільному доступу до ринку праці, організацію безпечного бізнес-середовища та стимулювання конкурентоспроможності, розвиток освіти, охорони здоров'я та заходів щодо зменшення бідності тощо.
\end{abstract}

Ключові слова: еколого-економічний розвиток, национальная экономика, індекс інклюзивного розвитку, соціальні аспекти, конкурентоспроможність.

В статье исследованы подходы к оценке стратегических ориентиров уровня эколого-экономического развития стран мира и обоснование внедрения индекса инклюзивного развития как принципа анализа экономической, экологической и социальной структуры мировой экономики. Исследовано понятие инклюзивного роста. Проанализированы основные показатели и методика фрормирования индекса инклюзивного развития (IDI). Проанализировано эколого-экономическое состояние топ 10 стран мира и Украины по индексу инклюзивного развития (IDI). Согласно индексу IDI Украина отнесена к развивающимся странам. Установлено, что среди них 
Украина имеет один из самых низких уровней доходов (49 из 79). Причиной данной ситуации можно назвать неравномерное распределение богатства по всему населению страны: высокий уровень «теневой» экономики; коррупционные сверхприбыли; а также необходимо отметить, большая часть доходов трудовых мигрантов тоже находятся в тени; недостоверной статистикой уровня доходов граждан и т.д. Все это приводит ко все большему разрыву между богатыми и бедными, сокращая средний класс. Украина, на основе опыта развитых стран, может провести мероприятия, реформы и т.д., направленные на экономическое развитие, улучшение социального и экологического состояния, снизить нагрузку на менее защищенный слой граждан страны на разных уровнях (налогообложение, дотации, свободное получение образовательных услуг, медицинской помощи и т.п.). Можно утверждать, что экономическое, социальное, экологическое развитие Украины по сравнению с развитыми странами характеризуется неравномерностью. Следовательно, создает необходимость в новых подходах, концепциях, моделях для уменьшения диспропорциональности Украины. Отмечено, что низкий показатель инклюзивного развития Украины свидетельствует о наличии инфраструктурных проблем, недостатков диверсификации экономики, угроз для инвестиционного климата и экологические проблемы (радиационное загрязнение, состояние атмоссрерного воздуха, состояние водных ресурсов, деградация почв, отходы, потеря биоразнообразия и т.д.). С этой позиции, концепция инклюзивного развития может обеспечить реализацию принципов стабильного и сбалансированного экономического, социального и экологического развития. Для Украины принятие во внимание опыт развитых стран, разработка и реализация инклюзивно-ориентированных программ позволит стабилизировать социально-экономическую ситуацию в стране, а также уменьшить неравномерность в разных сфрерах общественной жизни, фрормируя такую открытую политику и экономику, которая предполагала бы привлечение всех слоев населения к участию в распределении ресурсов и свободном доступе к рынку труда, организации безопасной бизнес-среды и стимулировании конкурентоспособности, развитии образования, здравоохранения и мер по уменьшению бедности и т.д.

Ключевые слова: эколого-экономическое развитие, государственная экономика, индекс инклюзивного развития, социальные аспекты, конкурентоспособность.

The article examines the approaches to assessing the strategic guidelines of the level of ecological and economic development of the world and the rationale for the introduction of the index of inclusive development as a principle of analysis of economic, environmental and social structure of the world economy. The concept of inclusive growth is studied. The main indicators and methods of forming the Inclusive Development Index (IDI) are analyzed. The ecological and economic condition of the top 10 countries of the world and Ukraine according to the index of inclusive development (IDI) is analyzed. According to the IDI index, Ukraine is classified as a developing country. It is determined that among them Ukraine has one of the lowest income levels (49 out of 79). The reason for this situation can be called the uneven distribution of wealth in relation to the entire population of the country: a high level of "shadow" economy; corrupt profits; and it should be noted that most of the income of migrant workers is also in the shadows; unreliable statistics on the level of income of citizens, etc. All this leads to a widening gap between rich and poor, reducing the middle class. Based on the experience of developed countries, Ukraine can carry out measures, reforms, etc. aimed at economic development, improving social and environmental conditions, reduce the burden on the less vulnerable at different levels (taxation, subsidies, free education, health care, etc.). It can be argued that the economic, social, environmental development of Ukraine in comparison with developed countries is characterized by unevenness. Consequently, it creates a need for new approaches, concepts, models to reduce the disproportion of Ukraine. It is noted that the low rate of inclusive development of Ukraine indicates the presence of infrastructural problems, shortcomings in economic diversification, threats to the investment climate and environmental problems (radiation pollution, air quality, water resources, soil degradation, waste, biodiversity loss, etc.). From this point of view, the concept of inclusive development can ensure the implementation of the principles of stable and balanced economic, social and environmental development. For Ukraine, taking into account the experience of developed countries, development and implementation of inclusive programs will stabilize the socio-economic situation in the country, as well as reduce inequality in various spheres of public life, forming an open policy and economy that would involve all segments of the population. to participate in the allocation of resources and free access to the labor market, the organization of a secure business environment and the promotion of competitiveness, the development of education, health care and poverty reduction measures, etc.

Keywords: ecological and economic development, national economy, index of inclusive development, social aspects, competitiveness.

Постановка проблеми. За умови постійного економічного розвитку, економічна діяльністю людини охопила усі континенти планети Земля, перед людством все гостріше постають екологічні проблеми, як у регіональному так і у глобальному масштабі, як щодо збільшення обсягів шкідливих викидів, так і щодо вичерпання природних ресурсів. Одним
3 основних стратегічних орієнтирів подальшого еколого-економічного розвитку країн $\epsilon$ «Індекс інклюзивного розвитку» (Inclusive Development Index, IDI) покликаний інорормувати суспільство, аналізувати рівень сталого і інклюзивного економічного розвитку, а також робити напрацювання в сфрері забезпечення різнопланового розвитку людства. 
Аналіз останніх досліджень і публікацій. Засади теорії еколого-орієнтованого, інклюзивного розвитку закладені дослідженнями переважно закордонних вчених: 3.М. Бедос, Д. Робінсон, Е.С. Райнерт та інші. Базові положення, що розроблялися під керівництвом цих вчених, були в подальшому розвинені провідними представниками бізнесу, та закладені державними структурами в стратегії екологоекономічного розвитку країн.

Основною метою полягає в дослідженні підходів до оцінювання стратегічних орієнтирів рівня еколого-економічного розвитку країн світу та обґрунтування запровадження індексу інклюзивного розвитку як принципу аналізу економічної, екологічної та соціальної структури світової економіки.

Виклад основного матеріалу дослідження. Поняття «інклюзивність» має широке значення і реалізоване в багатьох аспектах, у зв'язку з чим в економічній літературі розглядаються поняття «інклюзивний розвиток», «інклюзивна економіка», «інклюзивне зростання», «інклюзивні інновації» [1].

До числа заходів, пропонованих для вирішення соціальних, екологічних та економічних проблем, пов'язаних з глобалізацією економіки відноситься концепція інклюзивного стійкого зростання. її базові положення було викладено у звіті Комісії по зростанню і розвитку ООН у 2008 році, яку очолив лауреат Нобелівської премії М. Спенс «The growth report. Strategies for Sustained Growth and Inclusive Development» [4, c. 94].

На даний час не існує єдиного визначення поняття «інклюзивне зростання». Так, Світовий банк визначає інклюзивне зростання як високе та стійке (важлива умова скорочення бідності), широко поширене у всіх секторах економіки, що залучає значну частину трудової сили і характеризується рівністю можливостей у доступі до ринку та ресурсів. Європейська комісія при підготовці стратегії «Європа 2020» позначає, інклюзивне зростання включає в себе: повне використання трудового потенціалу, зниження бідності та її наслідків, розвиток соціальної залученості, усунення регіональних диспропорцій.

У Звіті ОЕСР 2014 р. «Усі на борт: Реалізація інклюзивного зростання на практиці» поняття «інклюзивне зростання» розуміється як «новий підхід до розуміння економічного зростання, спрямований на підвищення рівня життя і більш рівномірний розподіл переваг від збільшеного добробуту серед соціальних груп». ОЕСР наголошує на необхідність переходу від традиційного підходу, який використовує в якості вирішального показника фрункціонування наших економік зростання ВВП на душу населення, до розуміння, яке виходить за межі понять доходу і матеріального рівня життя і включає негрошові величини, що служать підставою для процвітання, і результатів розподілу впливів від політичних заходів [5].

Нова система індикаторів була запропонована на Всесвітньому економічному форумі в Давосі (23-26 січня 2018 р.). Новій системі дали назву «індекс інклюзивного розвитку» (Inclusive Development Index, IDI). Він повинен «інформувати суспільство і допомагати сталого і інклюзивного економічного розвитку». Цей показник включає 12 індикаторів, згрупованих у три групи (табл. 1). 3 показників кожної групи розраховуються спочатку групові індекси, а потім складається підсумковий - їх середнє арифметичне [4, с. 96].

Показники та індикатори індексу інклюзивного розвитку (IDI)

Таблиця 1

\begin{tabular}{|c|c|}
\hline \multirow{4}{*}{$\begin{array}{l}\text { Зростання та } \\
\text { розвиток }\end{array}$} & ВВП на душу населення (дол. США) \\
\hline & Продуктивність праці - ВВП на одного працівника (дол. США) \\
\hline & Очікувана тривалість здорового життя (роки) \\
\hline & Зайнятість населення відсотки \\
\hline \multirow{4}{*}{ Інклюзивність } & $\begin{array}{l}\text { Коефіцієнт розшарування суспільства за доходами (від 0, тобто без } \\
\text { розшарування, до 100) }\end{array}$ \\
\hline & Рівень бідності (відсотки) \\
\hline & $\begin{array}{l}\text { Коефріцієнт розшарування суспільства за розподілом багатства (від 0, тобто } \\
\text { без нерівності, до 100) }\end{array}$ \\
\hline & Медіанний дохід (дол. США) \\
\hline \multirow{4}{*}{$\begin{array}{l}\text { Наступність } \\
\text { поколінь } \\
\text { і стійкість } \\
\text { розвитку }\end{array}$} & Скориговані чисті заощадження (відсотки від валового національного доходу) \\
\hline & Парникова інтенсивність ВВП (кілограми викидів вуглекислого газу на долар) \\
\hline & Державний борг (відсотки від ВВП) \\
\hline & Коесіцієнт демограсрічного навантаження (відсотки) \\
\hline
\end{tabular}


Такий комплексний показник, на думку Всесвітнього економічного фроруму, відображає більш цілісну картину економічного розвитку, якщо його мета - стійке підвищення рівня життя населення, а не просто збільшення виробництва товарів і послуг.

Якщо не забезпечується інклюзивний розвиток, то потенційні темпи зростання економіки, навіть незважаючи на зростання ВВП, знижуються. Низький показник інклюзивного розвитку свідчить про наявність інфрраструктурних проблем, недоліків в диверсифрікації економіки і загроз для інвестиційного клімату. Таким чином, даний показник може бути вельми корисний, в тому числі, для інвесторів [4, с. 97].

Проаналізуємо еколого-економічний стан топ 10 країн світу та України за індексом інклюзивного розвитку (IDI) за 2018 р. у табл. 2:

Норвегія другий рік поспіль очолює Індекс інклюзивного розвитку як найбільш інклюзивна економіка світу, демонструючи високі результати. У світлі коливання видобутку насрти та газу країна проводить жорстку фріскальну політику для стимулювання економічного зростання в інших секторах, окрім нафтового, оскільки вона має другий за величиною ВВП на душу населення, четвертий за рівнем продуктивності праці та п'ятий за рівнем зайнятості серед розвинених економік. Довгострокове бачення Норвегії щодо сталої та інклюзивної економіки підтверджується низькою нерівністю доходів (2-е місце), високим середнім рівнем життя (1-е) та низькими викидами вуглецю (3-е). Хоча він має один із найвищих рівнів нерівності у статках у своїй групі країн, це пояснюється потужними та щедрими програмами соціального захисту Норвегії щодо пенсій, освіти та державного житла, що створює диспропорцію в особистих фрінансових активах. В цілому, Норвегія виступає надзвичайно добре у сприянні інклюзивному зростанню та розвитку, незважаючи на незначне зниження (табл. 3) цього показника за останні п'ять років $[7$, с. 8].

Індекс Джині (Gini Index) вимірює ступінь, в який розподіл доходів або витрат на споживання окремих осіб або домогосподарств в економіці відрізняється від абсолютної рівності в розподілі. Крива Лоренца показує кумулятивний відсоток загального доходу, отриманого від загального числа одержувачів, починаючи з найбідніших індивідів або домогосподарств. Індекс Джині вимірює площу між Кривою Лоренца i гіпотетичною лінією абсолютної рівності, вираженої як відсоток від максимальної площі під Кривою. Таким чином, коли індекс Джині дорівнює 0, це означає повну рівність, в той час як показник 100 означає абсолютну нерівність.

Австралія посідає 9 місце серед 30 країн 3 розвиненою економікою, охоплених Індексом інклюзивного розвитку 2018 (IDI), і першою не європейською країною. Проте результати діяльності країни за 12 компонентами Індексу $є$ нерівномірними. В країні високий рівень доходу, у поєднанні 3 високим рівнем зайнятості (61\% загальної чисельності населення), сприяє солідним результатам діяльності у ссрері зростання та розвитку IDI. Однак країна посідає лише середину рейтингу за продуктивністю праці та тривалістю життя. Зокрема, вуглецева інтенсивність

Таблиця 2

\begin{tabular}{|c|c|c|c|c|}
\hline \multirow[b]{3}{*}{ Країна } & \multicolumn{4}{|c|}{ Показники та індикатори індексу інклюзивного розвитку (IDI) } \\
\hline & \multicolumn{4}{|c|}{ Наступність поколінь і стійкість розвитку } \\
\hline & $\begin{array}{c}\text { Скориговані } \\
\text { чисті } \\
\text { заощадження } \\
\text { (\% від ВНД) }\end{array}$ & $\begin{array}{c}\text { Парникова } \\
\text { інтенсивність } \\
\text { ВВП (кг викидів } \\
\text { вугл. газу } \\
\text { на дол.) }\end{array}$ & $\begin{array}{c}\text { Державний борг } \\
\text { (відсотки } \\
\text { від ВВП) }\end{array}$ & $\begin{array}{c}\text { Коефріцієнт } \\
\text { демографрічного } \\
\text { навантаження } \\
\text { (відсотки) }\end{array}$ \\
\hline Норвегія & 20.6 & 16.3 & 33.2 & 52.5 \\
\hline Ісландія & 14.7 & 21.2 & 53.2 & 52.1 \\
\hline Люксембург & 20.9 & 32.5 & 22.6 & 44.0 \\
\hline Швейцарія & 17.9 & 11.8 & 45.4 & 49.4 \\
\hline Данія & 18.5 & 18.2 & 39.9 & 56.3 \\
\hline Швеція & 19.0 & 14.2 & 41.7 & 59.3 \\
\hline Нідерланди & 15.2 & 38.9 & 62.6 & 53.8 \\
\hline Ірландія & 26.2 & 19.5 & 76.4 & 54.5 \\
\hline Австралія & 8.1 & 57.1 & 41.1 & 51.9 \\
\hline Австрія & 12.7 & 22.6 & 83.9 & 49.5 \\
\hline Україна & 1.0 & 347.0 & 81.2 & 45.8 \\
\hline
\end{tabular}

Джерело: побудовано автором на основі [7] 
Таблиця 3

Тенденції країн за показниками IDI та Джині протягом 2013-2018 рр.

\begin{tabular}{|c|c|c|c|c|}
\hline Країна & $\begin{array}{c}\text { Загальна } \\
\text { оцінка IDI } \\
\text { (2018 р.) }\end{array}$ & $\begin{array}{c}\text { IDI тенденції } \\
\text { за 2013-2018 рр. } \\
\text { (\%) }\end{array}$ & $\begin{array}{c}\text { Індекс Джині } \\
\text { за добробутом } \\
2018 \text { (\%) }\end{array}$ & $\begin{array}{c}\text { Індекс Джині } \\
\text { тенденції за } \\
\text { добробутом } \\
\text { 2013-2018 рік (\%) }\end{array}$ \\
\hline Норвегія & 6.08 & -0.77 & 80.5 & 2.7 \\
\hline Ісландія & 6.07 & 12.58 & 46.7 & -20.6 \\
\hline Люксембург & 6.07 & 0.15 & 68.1 & 2.4 \\
\hline Швейцарія & 6.05 & 1.92 & 69.4 & -11.2 \\
\hline Данія & 5.81 & 4.76 & 80.9 & -26.8 \\
\hline Швеція & 5.76 & 0.48 & 83.4 & 3.1 \\
\hline Нідерланди & 5.61 & 0.43 & 73.0 & 0.2 \\
\hline Ірландія & 5.44 & 9.28 & 81.3 & 10.4 \\
\hline Австралія & 5.36 & 0.46 & 65.2 & 1.6 \\
\hline Австрія & 5.35 & -0.17 & 78.8 & 1.0 \\
\hline Україна & 3.42 & -6.80 & 90.1 & 0,1 \\
\hline
\end{tabular}

Джерело: побудовано автором на основі [7]

Австралії є однією з найвищих серед розвинених економік (25-е місце). Хоч нерівність багатства менша, ніж у більшості розвинених економік (8-е місце), нерівність доходів $€$ однією 3 найвищих із значенням коефріцієнта Джині 33,2 (22-е). Крім того, дані свідчать про те, що нерівність доходів і багатства зросла з 2012 року. Нарешті, на рівні 13\% (21-е місце) рівень бідності є високим і майже вдвічі вищим за середній показник у країнах Скандинавії [7, с. 7].

Ірландія посідає восьме місце серед країн 3 розвиненою економікою, демонструючи хороші результати у галузях зростання, розвитку, справедливості та сталості між поколіннями. Країна виграє від високого ВВП на душу населення та рівня продуктивності праці. Сприятливий діловий клімат дозволив Ірландії різко знизити рівень державного боргу на 43\% за останні п'ять років (табл. 3), що стало б найбільшим поліпшенням для будь-якої розвиненої економіки. Незважаючи на те, що середній рівень життя поступово підвищився, країна стикається з високою нерівністю доходів та зростаючою нерівністю в багатстві, оскільки її показник багатства Джині збільшився більш ніж на 10 пунктів за останні п'ять років. Ірландія працює над рівнем справедливості та сталого розвитку між поколіннями, що обумовлено відносно низькими викидами вуглецю, значними інвестиціями в людський капітал та низьким рівнем екологічної шкоди [7, с. 8].

Україна посідає 49-е місце серед країн, що розвиваються (79 країн), за Індексом інклюзивного розвитку, спрямований на підвищення рівня життя і більш рівномірний розподіл переваг. У порівнянні з Індексом інклюзивного розвитку за 2017 рік рейтинг упав на 2 пункти серед країн, що розвиваються, однак, залишається вищим, ніж 5 років тому. До причин різких коливань показників індексу України, насамперед, необхідно віднести нестабільну політичну, економічну та військову ситуації в країні. Як наслідок, уповільнення соціально-економічного розвитку суспільства, високий рівень трудової міграції (відтік працездатного населення, особливо серед молоді), що у свою чергу, пришвидшує старіння нації; зниження рівня залучення в країну інвестицій, а також впровадження науково-технічних інновацій в різні галузі виробництва.

Середдосліджуванихкраїн-Українамає один із найнижчих рівнів доходів (ВВП на душу населення країни у 2018 році складає - 2906 дол. США), в той час, як за індексом Джині за добробутом у 2018 році - 90,1\% (табл. 3). Причиною даної ситуації можна назвати нерівномірний розподіл багатства щодо всього населення країни: високий рівень «тіньової» економіки; корупційні надприбутки; а також необхідно відмітити, більша частина доходів трудових мігрантів теж знаходяться в тіні; недостовірною статистикою щодо рівня доходів громадян тощо. Усе це приводить до все більшого розриву між багатими та бідними, скорочуючи середній клас.

Україна на основі досвіду розвинених країн може провести заходи, реформи тощо спрямовані на економічний розвиток, покращення соціального та екологічного стану, знизити навантаження на менш захищений шар громадян країни на різних рівнях (оподаткування, дотації, вільне отримання освітніх послуг, медичної допомоги тощо).

У скандинавських країнах першочергово стоїть забезпечення високого рівня якості життя громадян. Тобто, таке соціальне середовище, в якому «людина» забезпечена усіма необхідними 


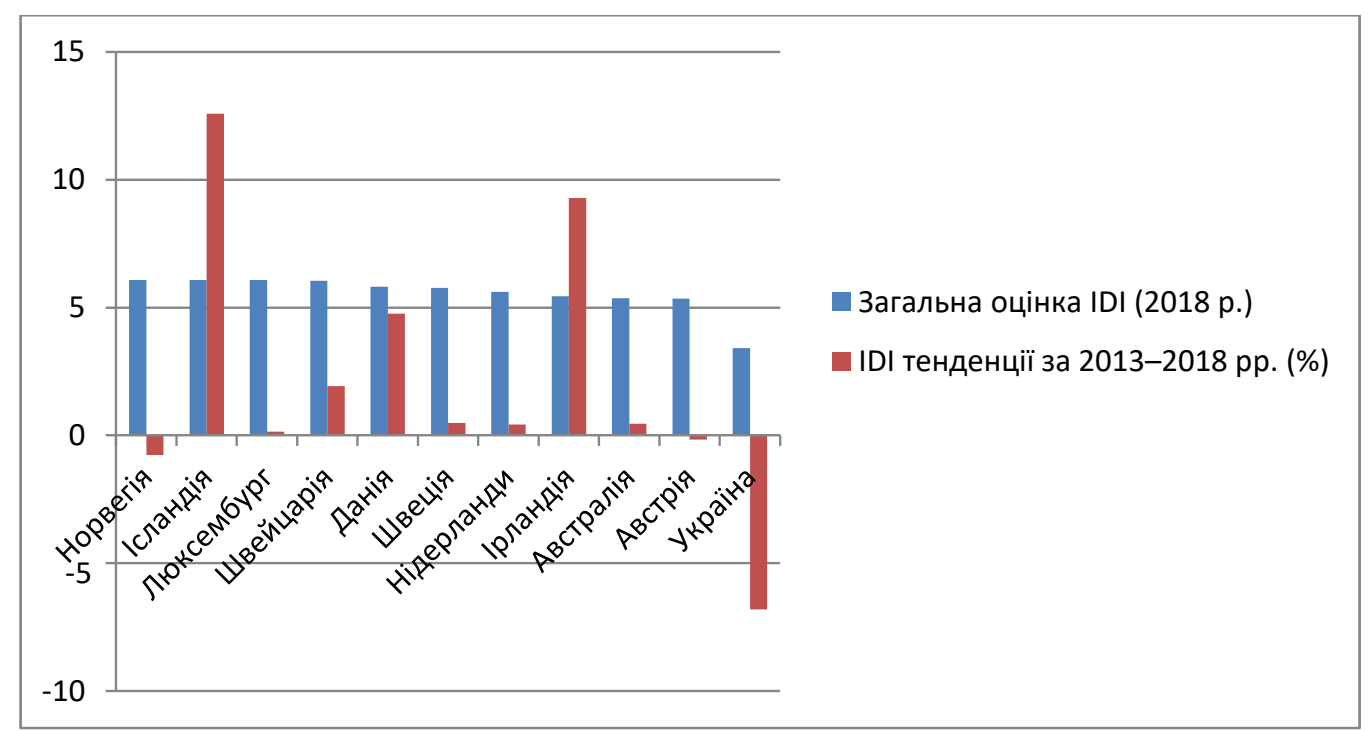

Рис. 1. Тенденції розвинених країн та України за показниками IDI та протягом 2013-2018 pp.

Джерело: побудовано автором на основі [7]

благами та захищена державою (наприклад, політична стабільність та безпека, статева рівність, стан навколишнього середовища тощо).

У Норвегії діє виборна система місцевих органів влади. Ті, хто живуть у комуні, мають право вибирати за принципом: одна людина один голос. Вибори в муніципальну раду, що складається з 15-16 депутатів, здійснюються за партійними списками. У Норвегії немає такої практики, коли якийсь підприємець або економічна сила прямо впливають на процес голосування. Політична та адміністративна системи дуже серйозно відділяють економічні інтереси від політичних [3, с. 215].

Гарним відправним пунктом для успішного розвитку України $€$ виявлення інтересів на місцевому рівні, де саме й відбувається реальний економічний та соціальний розвиток. Ефективна територіальна влада може найбільш вдало пристосуватися до місцевих особливостей і самостійно приймати важливі для регіону рішення. Якщо вона добре фрункціонує, то зменшується дистанція між тими, хто ухвалює рішення, і тими, хто споживає громадські послуги. Місцева демократія дає змогу громадянам брати участь у політичному житті регіону, а отже, впливати на власне повсякденне життя. Здійснення адміністративно-територіальної ресрорми в Україні $\epsilon$ дуже складним питанням, позаяк велика частина економічнихі політичних ресурсів контролюється центральними органами влади. Можливо, для вибору найкращого варіанта реформи Україні варто проаналізувати європейські моделі управління. У будь-якій країні існують різні погляди на такі питання і шляхи їх вирішення. Найбільш раціональним рішенням $€$ максимальне наближення органів влади до місцевих громад, де безпосередньо живуть та працюють люди [2].

Крім того, цікавим для України стане австралійський досвід $з$ оптимізації структури органів державної влади. У ході рефрормування структури уряду, відбулося об'єднання профрільних міністерств та передавання відповідних сорер до компетенції одного міністерства. Так, в Австралії виникли міністерства із комплексними повноваженнями, такі як Міністерство сталого розвитку, охорони навколишнього середовища, водних ресурсів, населення та громад чи Міністерство регіонального розвитку, місцевого самоврядування, мистецтва та спорту. Незважаючи на офріційне завершення ресрорми у 2007 р. уряд Австралії активно продовжує об'єднання сорер повноважень різних профрільних міністерств [3, с. 24].

Практика Австралії є корисною для України з точки зору реалізації Указу Президента України «Про оптимізацію системи центральних органів виконавчої влади» [6]. У цьому контексті важливим у сорері державного управління України $€$ усвідомлення того, що ресорми - це безперервний процес, який має відбуватися не лише у чітко визначених часових рамках, а також з огляду на динамічні умови розвитку політичної системи.

У питаннях підготовки та підвищення кваліорікації державних службовців в Україні, як і в Австралії, важливим $€$ запровадження короткострокових навчальних курсів та програм, які 
дозволять державним службовцям у короткий відтинок часу отримати нові знання та навички для ефрективного виконання покладених на них завдань. Створення пілотних проектів та програм дозволить як економити витрати на їх організацію, так і забезпечувати наповнення заходу при врахуванні актуальних тенденцій у сорері державного управління [3, с. 24].

Висновки 3 проведеного дослідження. Проаналізувавши за системою індикаторів, яка була запропонована на Всесвітньому економічному фрорумі в Давосі (23-26 січня 2018 р.), що має назву «індекс інклюзивного розвитку», розвинені країни та Україну можна стверджувати, що економічний, соціальний, екологічний розвиток України в порівнянні 3 розвиненими країнами характеризується нерівномірністю. А отже, створює необхідність у нових підходах, концепціях, моделях для зменшення диспропорційності України.

Також, необхідно відмітити, що низький показник інклюзивного розвитку України свідчить про наявність інфрраструктурних про- блем, недоліків в диверсифікації економіки, загроз для інвестиційного клімату та екологічні проблеми (радіаційне забруднення, стан атмосорерного повітря, стан водних ресурсів, деградація ґрунтів, відходи, втрата біорізноманіття тощо).

3 цієї позиції концепція інклюзивного розвитку може забезпечити реалізацію принципів стабільного та збалансованого економічного, соціального та екологічного розвитку. Для України прийняття до уваги досвід розвинених країн, розробка та реалізація інклюзивноорієнтованих програм дасть змогу стабілізувати соціально-економічну ситуацію в країні, а також зменшити нерівномірність у різних сорерах суспільного життя, формуючи таку відкриту політику та економіку, яка передбачала б залучення всіх верств населення до участі в розподілі ресурсів і вільному доступу до ринку праці, організацію безпечного бізнес-середовища та стимулювання конкурентоспроможності, розвиток освіти, охорони здоров'я та заходів щодо зменшення бідності тощо.

\section{СПИСОК ВИКОРИСТАНИХ ДЖЕРЕЛ:}

1. Інклюзивність економіки - нове мірило економічного росту. Київський міжнародний економічний форум. URL: https://forumkyiv.org/uk/news/inkljuzivnist-ekonomikinove-mirilo ekonomichnogo-rostu

2. Королівство Норвегія в сучасних міжнародних відносинах та у співпраці 3 Україною. URL: https:http://www.nbuv.gov.ua/portal/Soc_Gum/Nvdau/2009_15/14.pdf

3. Світові моделі державного управління: досвід для України / за заг. ред. Ю.В. Ковбасюка, С.В. Загороднюка, П.І. Крайніка, Х.М. Дейнеги. Київ : НАДУ, 2012. 612 с.

4. Ткаліч Т.І. Інклюзивна економіка як модель світового економічного зростання. Науковий вісник МнУ імені Сухомлинського. 2018. № 1(10). С. 94-99.

5. Кэти Хоуп У восьми миллиардеров больше денег, чем у 3,6 млрд бедняков 16 января 2017. URL: https://www.bbc.com/russian/features-38639948 (дата звернення: 15.06.2018).

6. Указ Президента України "Про оптимізацію системи центральних органів виконавчої влади". URL: http://www.president.gov.ua/documents/12584.html

7. The Inclusive Growth and Development Report 2017 is published by the World Economic Forum. URL: http://www3.weforum.org/docs/WEF_Forum_IncGrwth_2017.pdf.

\section{REFERENCES:}

1. Inklyuzivnist ekonomiki - nove mirilo ekonomichnogo rostu. Kiyivskij mizhnarodnij ekonomichnij forum. Retrieved from: https://forumkyiv.org/uk/news/inkljuzivnist-ekonomikinove-mirilo ekonomichnogo-rostu

2. Korolivstvo Norvegiya $v$ suchasnikh mizhnarodnikh vidnosinakh ta $u$ spivpraczi $z$ Ukrayinoyu. Retrieved from: https:http://www.nbuv.gov.ua/portal/Soc_Gum/Nvdau/2009_15/14.pdf

3. Svitovi modeli derzhavnogo upravlinnya: dosvid dlya Ukrayini (2012) / za zag. red. Yu.V. Kovbasyuka, S.V. Zagorodnyuka, P.I. Krajnika, Kh.M. Dejnegi. Kyiv: NADU, 612 p.

4. Tkalich T.I. (2018) Inklyuzivna ekonomika yak model svitovogo ekonomichnogo zrostannya. Naukovyi visnik MNU imeni Sukhomlinskogo, 1(10), pp. 94-99.

5. Keti Khoup U vosmi milliarderov bolshe deneg, chem u 3,6 mlrd bednyakov 16 yanvarya 2017 . Retrieved from: https://www.bbc.com/russian/features-38639948

6. Ukaz Prezidenta Ukrayini "Pro optimizacziyu sistemi czentralnikh organiv vikonavchoyi vladi". Retrieved from: http://www.president.gov.ua/documents/12584.html

7. The Inclusive Growth and Development Report 2017 is published by the World Economic Forum. Retrieved from: http://www3.weforum.org/docs/WEF_Forum_IncGrwth_2017.pdf 